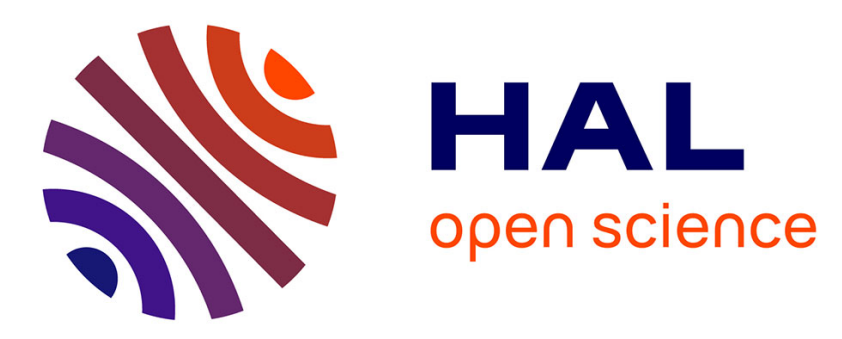

\title{
Simple urea-glutaraldehyde mix used as a formaldehyde-free adhesive: effect of blending with nano-AlO
}

\author{
M. Ł. Mamiński, M. E. Król, M. Grabowska, P. Gluszyński
}

\section{- To cite this version:}

M. Ł. Mamiński, M. E. Król, M. Grabowska, P. Gluszyński. Simple urea-glutaraldehyde mix used as a formaldehyde-free adhesive: effect of blending with nano-AlO. European Journal of Wood and Wood Products, 2010, 69 (3), pp.505-506. 10.1007/s00107-010-0482-2 . hal-00620890

\section{HAL Id: hal-00620890 https://hal.science/hal-00620890}

Submitted on 9 Sep 2011

HAL is a multi-disciplinary open access archive for the deposit and dissemination of scientific research documents, whether they are published or not. The documents may come from teaching and research institutions in France or abroad, or from public or private research centers.
L'archive ouverte pluridisciplinaire HAL, est destinée au dépôt et à la diffusion de documents scientifiques de niveau recherche, publiés ou non, émanant des établissements d'enseignement et de recherche français ou étrangers, des laboratoires publics ou privés. 


\title{
Simple urea-glutaraldehyde mix used as a formaldehyde-free adhesive: effect of blending with nano- $\mathrm{Al}_{2} \mathrm{O}_{3}$
}

\author{
M. Ł. Mamiński*, M. E. Król, M. Grabowska, P. Głuszyński \\ Warsaw University of Life Sciences - SGGW, Faculty of Wood Technology, \\ 159 Nowoursynowska St., 02-776 Warsaw, Poland \\ *corresponding author: mariusz_maminski@sggw.pl
}

\begin{abstract}
A formaldehyde-free adhesive based on urea (U) and glutaraldehyde (GA) was developed. High reactivity of the urea-glutaraldehyde mix at ambient temperature allows for its cold setting. The glues of GA/U molar ratio between 0.8 and 1.2 were examined. It was found that for the satisfactory performance of the system, blending with nano- $\mathrm{Al}_{2} \mathrm{O}_{3}$ was necessary.
\end{abstract}

\section{Introduction}

Since formaldehyde has been classified as carcinogenic to human (IARC 2004), the requirements urea-formaldehyde resins must meet have become stricter and an urgent need for a reduction of its content and emission from wood based materials and adhesives occurred. E0 (known as $\mathrm{F}^{* * *}$ ) class means formaldehyde emission below $3 \mathrm{mg} / 100 \mathrm{~g}$ while that for Super E0 (also known as $\mathrm{F}^{* * * *}$ ) is below $2 \mathrm{mg} / 100 \mathrm{~g}$ (JIS A 5905, JIS A 5908:2003). There are several approaches allowing to overcome that problem: (1) development of adhesives based on renewable resources - e.g. soy proteins (Kumar et al. 2002), tannins (Ballerini et al. 2005) or chitosane (Umemura et al. 2003); (2) replacement of formaldehydeemitting adhesives - namely urea-formaldehyde - with other types of adhesives (e.g. polyurethanes); (3) addition of formaldehyde scavengers to the glue formulation (e.g. liquefied wood (Medved et al. 2009), acetoacetyl moieties (Dziurka and Łęcka 2004) or urea 
which is used in industry up to date); (4) adhesive reformulating and/or partial substitution of formaldehyde with other aldehydes. In literature, there are some reports on the application of succinaldehyde or propionic aldehyde in adhesives (Manosuri and Pizzi 2006; Wang and Pizzi 1997).

In the proposed solution, formaldehyde was replaced by glutaraldehyde - an industrial aldehyde used as a disinfecting agent or proteins-crosslinking agent (Kupec et al. 2003) - so that urea-glutaraldehyde (UGA) adhesive was obtained. However, it must be stressed that glutaraldehyde is less toxic than formaldehyde. Glutaraldehyde $\mathrm{LD}_{50}$ value (oral, rat) is 1470 $\mathrm{mg} / \mathrm{kg}$ (Sigma-Aldrich 2008), while that for formaldehyde is $100 \mathrm{mg} / \mathrm{kg}$ (NTIS 2005).

Also, since it is known that nanoparticles may greatly improve adhesive interactions with a substrate (Zhai et al. 2007) the prepared urea-glutraldehyde mix was blended with $\mathrm{Al}_{2} \mathrm{O}_{3}$ nanopowder. The approach allowed for the development of a cold setting formaldehyde-free urea-based adhesive for wood bonding.

\section{Materials and methods}

The raw UGA mix was prepared by simply dissolving a calculated amount of urea in a respective amount of 50\% aqueous glutaraldehyde solution (Aldrich) to finally achieve the required molar ratio of the reagents (e.g. $30 \mathrm{~g}$ of urea in $100 \mathrm{~g}$ of $50 \%$ GA solution for 1.0 GA/U molar ratio). Mixing (100 revolutions per minute) was kept at room temperature until complete dissolving of urea, so that the procedure required no typical and laborious resin synthesis.

Formulations with GA/U molar ratio of $0.8,1.0$ and 1.2 were prepared. $1 \%$ wt or $3 \%$ wt of nano- $\mathrm{Al}_{2} \mathrm{O}_{3}$ (Aldrich) dispersions - based on solids - were obtained by addition of nanomaterial to the urea / glutaraldehyde solution followed by 30 -min-ultrasonication. $1 \%$ aqueous oxalic acid (10 $\mathrm{g}$ of solution in $100 \mathrm{~g}$ of glue composition) used as hardener was 
added to the UGA mixture prior to bonding. Final solids contents were as follows: $58 \%, 56 \%$ and $60 \%$, respectively, for $0.8,1.0$ and $1.2 \mathrm{GA} / \mathrm{U}$ molar ratio. After the time necessary for the system to achieve application viscosity of $1000 \mathrm{cP}$ (Table 1), the glue was applied onto the specimens. Glue load was $160 \mathrm{~g} / \mathrm{m}^{2}$. Solid beech specimens (density $620 \mathrm{~kg} / \mathrm{m}^{3}, 5.6 \%$ moisture content) cut according to EN 205 were bonded at ambient temperature (30 min, 1.5 $\left.\mathrm{N} / \mathrm{mm}^{2}\right)$. The manufactured samples - after 7 days in controlled climate $\left(20^{\circ} \mathrm{C}\right.$, humidity $65 \%$ ) - were subjected to dry shear strength tests (no. of samples was 20 ).

\section{Results and discussion}

From the data shown in Table 1 it is clear that reactivity of the adhesive is high - even at ambient temperature gellation occurs in 70 - 100 min without any hardener. However, it can be easily shortened to minutes with small addition of an acid. The gellation experiments and physical analysis of the adhesive after curing showed that $\mathrm{GA} / \mathrm{U}=1.0$ molar ratio was most suitable. The 0.8 and 1.2 options provided poor mechanical performance and brittleness of the cured polymer. Thus, wood bonding and blending with nano- $\mathrm{Al}_{2} \mathrm{O}_{3}$ was performed for $\mathrm{GA} / \mathrm{U}$ $=1.0$ only. The strengths of the gluelines are shown in Table 2 . The presented values obtained for the acid-cured series with $\mathrm{Al}_{2} \mathrm{O}_{3}$ exceeded shear strength of the substrate and $100 \%$ wood failure was observed, while the controls exhibited adhesive failure and strengths lower by 52 and $34 \%$. By comparing strengths of non- $\mathrm{Al}_{2} \mathrm{O}_{3}$ blended series with and without hardener, it can be noticed that values of the hardened series are much higher, which suggests that acid hardener is necessary for the system. On the other hand, low strength values of the $\mathrm{Al}_{2} \mathrm{O}_{3}$ blended series without hardener suggest that sole presence of nanoparticles did not provide significant changes in shear strengths. 
Table 1

Table 2

\section{Conclusion}

Thus, the observations allow for withdrawing the conclusions that by simple dissolving of urea in glutaraldehyde solution a formaldehyde-free cold-setting adhesive system can be made. Its acid-curing significantly improves the adhesive performance, however, a synergetic effect of small addition of $\mathrm{Al}_{2} \mathrm{O}_{3}$ nanoparticles and acid curing is necessary for satisfactory shear strengths exceeding that of the substrate.

\section{References}

Ballerini A, Despres A, Pizzi A (2005) Non-toxic, zero emission tannin-glyoxal adhesives for wood panels. Holz Roh Werkst 63: 477-478

Dziurka D, Łęcka J (2004) The effect of introducing acrylic emulsions grafted with acetoacetyl groups on the properties of particleboards. J Appl Polym Sci 91: 2256-2264

EN 205 (2005) Test methods for wood adhesives for non structural applications Determination of tensile strength of lap joints

IARC, Press Release No. 153, 2004, IARC classified formaldehyde as carcinogenic to humans. http://www.iarc.fr/en/media-centre/pr/2004/pr153.html

Japanese Industrial Standards A 5905, A 5908:2003

Kupec J, Charvátová K, Navrátil M, Křesálek V, Křesálková M (2003) Effect of cross-linking waste protein with dialdehydes on its biodegradation under anaerobic conditions. J Polym

Environ 11: 93-100 
Kumar R, Choudhary V, Mishra S, Varma IK, Mattiason B (2002) Adhesives and plastics based on soy protein products. Ind Crops Prod 16: 155-172

Mansouri HR, Pizzi A (2006) Urea-formaldehyde-propionaldehyde physical gelation resins for improved swelling in water. J Appl Polym Sci 102: 5131-5136

Medved S., Šega B, Kunaver M, Šernek M (2009) Liquefied wood as formaldehyde scavenger for wood-based panels. Proc. of International Panel Products Symposium, Nantes, France, p. 61-69

NTIS - National Technical Information Service (2005) Formerly U.S. Clearinghouse for Scientific \& Technical Information. ADA125-539 (Springfield, VA 22161) Sigma-Aldrich Co. (2008) Material Safety Data Sheet Umemura K, Inoue A, Kawai S (2003) Development of new natural polymer-based wood adhesives I: dry bond strenth and water resistance of konjac glucomannan, chitosan and their composites. J Wood Sci 49: 221-226

Wang S, Pizzi A (1997) Succinaldehyde induced water resistance improvements of UF wood adhesives. Holz Roh Werkst 55: 9-12

Zhai LL, Ling GP, Wang YW (2007) Effect of nano-A12O3 on adhesion strength of epoxy adhesive and steel. Int J Adhes Adhes 28: 23-28 
ejwwp482_source.pdf

Table 1. Gelling times and application viscosity development of the studied UGA glues at $20^{\circ} \mathrm{C}$

Tabelle 1 Gelierzeiten und Dauer bis zum Erreichen der georderten Viskosität der untersuchten UGA-Klebstoffe bei $20^{\circ} \mathrm{C}$

\begin{tabular}{|c|c|c|c|}
\hline \multirow{2}{*}{$\begin{array}{c}\mathrm{GA} / \mathrm{U} \\
\text { molar ratio }\end{array}$} & \multicolumn{2}{|c|}{ Gelling time } & \multirow{2}{*}{$\begin{array}{c}1000 \mathrm{cP} \\
\text { achieved after } \\
{[\mathrm{min}]}\end{array}$} \\
\hline & $\begin{array}{l}\text { 1\% oxalic acid } \\
\text { [min] }\end{array}$ & $\begin{array}{c}\text { no hardener } \\
\text { [min] }\end{array}$ & \\
\hline 0.8 & 7.5 & 70 & 5 \\
\hline 1.0 & 10 & 70 & 8 \\
\hline 1.2 & 16 & 100 & 13 \\
\hline
\end{tabular}


ejwwp482_source.pdf

Table 2. Shear strengths of $\mathrm{GA} / \mathrm{U}=1.0$ glue blended with $\mathrm{Al}_{2} \mathrm{O}_{3}$

Tabelle 2 Scherfestigkeiten von $\mathrm{GA} / \mathrm{U}=1,0$ Klebstoff gemischt mit $\mathrm{Al}_{2} \mathrm{O}_{3}$

\begin{tabular}{|c|c|c|}
\hline \multirow[t]{2}{*}{$\begin{array}{l}\mathrm{Al}_{2} \mathrm{O}_{3} \\
{[\mathrm{wt} \%]}\end{array}$} & \multicolumn{2}{|c|}{$\begin{array}{c}\text { Shear strength } \\
{\left[\mathrm{N} / \mathrm{mm}^{2}\right]}\end{array}$} \\
\hline & $1 \%$ oxalic acid & no hardener \\
\hline 0.0 & $2.83 \pm 0.83$ & $1.40 \pm 0.51$ \\
\hline 1.0 & $5.91 \pm 0.78$ & $0.90 \pm 0.22$ \\
\hline 3.0 & $4.85 \pm 0.90$ & $0.85 \pm 0.25$ \\
\hline
\end{tabular}

